\title{
Design of Novel Bainitic Steels: Moving From Ultra Fine To Nanoscale Structures
}

\author{
F.G. Caballero ${ }^{1}$, C. Garcia-Mateo ${ }^{1}$ and M.K. Miller $^{2}$
}

${ }^{1}$ National Center for Metallurgical Research (CENIM-CSIC); Avda Gregorio del Amo, 8; Madrid, E-28040, Spain. fgc@cenim.csic.es

${ }^{2}$ Oak Ridge National Laboratory (ORNL), PO Box 2008; Oak Ridge, TN 37831-6139, USA

The concepts of phase transformation theory can be exploited to design nanostructured steels that transform to bainite at temperatures as low as $150{ }^{\circ} \mathrm{C}$. The microstructure obtained is so refined that it is possible to achieve a strength in excess of $2.5 \mathrm{GPa}$ in a material which has considerable toughness $\left(40 \mathrm{MPam}^{1 / 2}\right.$ ). Such combination of properties has never been achieved before with bainite. A description of the characteristics and significance of this remarkable microstructure in the context of the mechanism of transformation is provided.

\section{Advanced bainitic steels ready for the Nano Era}

There is a growing current awareness of the potential benefits of nanoengineering in the modern steel industry, and leading research and development institutes and companies are pursuing research in the area of nanostructured steels. In this industry, the term ultra-fine grained is generally used to describe steels with average grain sizes between 1 and $2 \mu \mathrm{m}$ and the term submicron (submicrometre) structure to refer to grain sizes between 100 and $1000 \mathrm{~nm}$. Until recently, effective processing techniques to reduce the grain size of these materials to less than $100 \mathrm{~nm}$ did not exist.

There are major difficulties in creating novel nanostructures that have a combination of properties appropriate for large scale applications. An important requirement is to be able to manufacture large 3-dimensional nanostructured components. In addition, the material concerned must be cost effective to produce, if it is not to be limited to niche applications. Severe deformation by methods, such as mechanical milling, equal channel angular processing and high pressure torsional straining, has not succeeded in this respect. Although mechanical milling and alloying can produce powders containing nanosized grains, grain growth cannot effectively be suppressed during consolidation processes such as sintering and hot pressing. Therefore, processing bulk 
nanoscrystalline materials for structural applications still poses a significant challenge, particularly in achieving an industrially viable process. Various processing strategies and alloy developments currently being explored in the modern steel industry that have the potential for creating extremely strong and affordable nanostructured engineering steels have been recently reviewed elsewhere [1].

In the case of ferritic steels, it is possible to move from ultra-fine to nanoscale by bainite reaction without the use of severe deformation, rapid heat-treatment or mechanical processing. This new generation of steels has been designed in which transformation at low temperature leads to a nanoscale microstructure consisting of extremely fine, 20 40-nm-thick, plates of ferrite and retained austenite [2-9]. These microstructures are achieved through isothermal transformation to bainite of high carbon high silicon steels with low martensite start temperature $\left(\sim 120^{\circ} \mathrm{C}\right)$. This is a process similar to that applied to well known commercial steels such as 100Cr6, for particular applications such as diesel injectors or large bearings [10]. Nanostructured bainitic steels present the highest strength/toughness combinations ever recorded in bainitic steels $(\sim 2.5$ GPa/40MPam1/2) [11,12] and exceptional rolling-sliding wear performances $[13,14]$. The main objective of this paper is to illustrate the characteristics and significance of this remarkable microstructure in the context of the mechanism of transformation.

\section{Low temperature bainite and slow transformation kinetics}

In general, low transformation temperatures are associated with fine microstructures which in turn generally possess both strength and toughness. There is, in principle, no lower limit to the temperature at which bainite can be generated according to bainite transformation theory [15]. Thermodynamics calculations by Caballero and Bhadeshia $[3,16]$ showed that it should be possible to obtain bainite at room temperature, but kinetics predicted that the transformation time would be approximately 100 years. An appropriate alloy was made ten years ago to test this theory. Two samples were archived; one at Cambridge University and the other at the Science Museum in London. The samples are sealed in quartz tubes containing pure argon. The tubes will be broken in a hundred years to see whether bainite has formed and to conduct detailed characterization. The samples were polished to a mirror finish so that any phase change will be evident in the mean time, through surface rumples caused by transformation.

The theoretical design procedure described elsewhere $[9,17]$ was used to produce, in a reasonable time, the finest possible bainitic structure by transformation at the lowest 
possible temperature [3,16]. From the models, the so-called NANOBAIN steel compositions in Table 1 were defined to decrease bainite transformation temperature, increase the maximum volume fraction of bainite in the final microstructure, and improve the hardenability of the steels. The carbon concentration was selected from calculations to suppress the $\mathrm{B}_{\mathrm{S}}$ temperature, with the aim of obtaining extremely thin platelets of bainite.

The bainite reaction in NANOBAIN 1 steel was found to take between 2 and some 90 days to complete the transformation within the temperature range $125-325^{\circ} \mathrm{C}[3,16]$, as illustrated in Fig. 1. Slow reactions give the ability to transform large components to a uniform microstructure free from residual stresses or complex processing. However, in a commercial scenario, there may be a need for more rapid heat treatment. Anything which enhances the nucleation rate will accelerate transformation, and the most common way of doing this is by refining the austenite grain size. The number density of nucleation sites increases inversely with the austenite grain size. By deforming the austenite, often referred to as 'pancaking' the austenite grains, the amount of austenite grain boundary area per unit volume may be further increased; the increase in grain surface area can be predicted quantitatively [18]. If the austenite is left in the deformed state then other defects such as shear bands and dislocations may also contribute to the nucleation rate. However, such defects can, in the case of displacive transformations, retard kinetics by a phenomenon known as mechanical stabilisation [19].

Another technique is to increase the magnitude of the free energy change accompanying the decomposition of austenite, $\left(\Delta G^{\gamma \alpha}=G^{\alpha}-G^{\gamma}\right)$ i.e., the driving force for transformation, by making controlled additions of substitutional solutes to the steel. Both the nucleation and the growth rates can be expected to increase as a function of $\left|\Delta G^{\gamma \alpha}\right|$. The addition of cobalt and aluminium in the first generation of NANOBAIN (detailed compositions are given in Table 1), boosts $\left|\Delta G^{\gamma \alpha}\right|$, causing the rate of transformation to increase [20]. The transformation was significantly accelerated to complete the processing within hours (as opposed to days), by making controlled additions of aluminium and cobalt, in concentrations less than $2 \mathrm{wt} \%$. A further rate increment was possible in NANOBAIN 4-12 alloys (Table 1) as kinetics data in Fig. 2 illustrates by reducing carbon, manganese, chromium, and molybdenum contents and by refining the prior austenite grain size with the help of niobium additions $[9,14]$. 


\section{Tensile properties of nanostructured bainitic steels}

The bainite obtained by low-temperature transformation is harder than ever previously achieved for this microstructure, with values in excess of $700 \mathrm{HV}$. Some strength and ductility data at room temperature are illustrated in Fig. 3. The ultimate tensile strengths (UTS) were always in excess of $2 \mathrm{GPa}$, with non-negligible ductility. The detailed analysis of the results clearly outlines two groups: 0.6C grades (NANOBAIN 9-12) do not exhibit significant difference in tensile properties as a function of composition. However, for the same transformation temperature, higher carbon grades $(1-0.8 \mathrm{C}$, NANOBAIN 4-8) exhibit higher tensile strengths (typically $2200 \mathrm{MPa}$ ) and lower elongations, except for NANOBAIN 7. A particular surprise is the NANOBAIN 7 alloy, with extraordinary combination of ductility and strength, $\sim 12 \%$ uniform elongation for UTS of $2 \mathrm{GPa}[12,14]$.

Much of the strength and hardness of the structure comes from the incredibly thin platelets of bainitic ferrite [11]. For a true thickness $t$, the mean lineal intercept $\bar{L} \cong 2 t$ [21], the resulting strengthening is given by $\Delta \sigma \cong 115(\bar{L})^{-1} \mathrm{MPa}$ where $\bar{L}$ is in micrometres $[22,23]$. The inverse dependence on $\bar{L}$, which does not follow the HallPetch relation, is because the transmission of slip across boundaries is determined by the energy required to expand dislocation loops rather than by the pile-up of the dislocations obstructed by boundaries [23]. The residue of strength after accounting for the plate thickness comes from dislocation forests, the intrinsic strength of the iron lattice and solution strengthening [11].

In a similar scheme, attempts to understand the origin of ductility in most specimens have been met with only partial success. Indeed, the selected microstructural parameters (retained austenite or bainitic ferrite content and lath thickness) fail to provide any indication of the ductility; see some results in Table 2, where similar parameters lead to significantly different ductility, with a clear difference in results when heat treating at $200 / 220{ }^{\circ} \mathrm{C}$ or $250 / 270{ }^{\circ} \mathrm{C}$. As an example, NANOBAIN 7 exhibits identical retained austenite and bainite lath thickness after heat treatment at 220 and $250{ }^{\circ} \mathrm{C}$, but its ductility is entirely different. It has been suggested that retained austenite mechanical stability is the key to the ductility in those microstructures [12,24]. 


\section{Nanoscale and complex ferritic structure}

Bright field TEM image of NANOBAIN 1 steel transformed at $125{ }^{\circ} \mathrm{C}$ for 60 days is presented in Fig. 4. Some of the plates of bainite are incredibly long and thin (20-40 $\mathrm{nm}$ ), giving an ultra-fine scale structure consisting of an intimate mixture of austenite and ferrite. Dislocation debris is evident in both the bainitic ferrite and the surrounding austenite. Extensive TEM failed to identify significant carbide precipitation in this low temperature bainite; only a few extremely fine (20 nm wide and $175 \mathrm{~nm}$ long) cementite particles in the bainitic ferrite were found in samples after extensive ageing at $200{ }^{\circ} \mathrm{C}$ for 14 days [2].

Ferrite laths in a bainite sheave are of nearly the same crystallographic orientation. The sheaves are sometimes called as packets in optical microscopy [25], as they are similar to those of lath martensite. In lath martensite structures, a prior austenite grain is divided into packets, the group of laths with the same habit plane (or the same parallel close-packed planes relationship) with respect to austenite, and each packet is further divided into blocks [26]. Each martensite block contains laths of the same orientation and was also called a co-variant packet [27]. Recently, the crystallography of bainite in $\mathrm{Fe}-9 \mathrm{Ni}-(0.15-0.5) \mathrm{C}($ wt.\%) alloys transformed at different temperatures was studied in detail by electron backscatter diffraction (EBSD) in scanning electron microscopy (SEM) [28]. It is known that the relative orientations of the bainitic ferrite and its parent austenite are always close to the classic Kurdjumov-Sachs (K-S) and NishiyamaWasserman (N-W) relationships [25]. From a single austenite grain, 24 crystallographic variants can be formed with a K-S orientation relationship and 12 with a $\mathrm{N}-\mathrm{W}$ orientation relationship due to the symmetry of cubic systems. The inverse pole figure colour map image in Fig. 5 shows the bainitic structure formed from an austenite grain at $250{ }^{\circ} \mathrm{C}$ in the NANOBAIN 9 steel. The colors correspond to the crystallographic orientation normal to the observed plane, representing different crystallographic variants. The boundaries were drawn where the misorientation angle is greater than $10^{\circ}$. The corresponding pole figure shows some orientation scattering from the ideal $\mathrm{N}-\mathrm{W}$ orientation relationship. The ideal $\mathrm{N}-\mathrm{W}$ orientations of the 12 variants are rotated to coincide with the actual $\{011\}$ pole figure of the measured transformed bainite (Fig. $5 b)$. Then each variant was accordingly identified on the orientation map (Fig. 5a). It is revealed that a prior austenite grain (Fig. 5c) was divided by packets consisting of three blocks of which the orientations are entirely different to each other. Each block contains a single variant of the bainitic lath. 


\section{Morphology and size of austenite}

The refinement of the microstructure to the nano-scale is not exclusive of the bainitic ferrite, as retained austenite trapped between the slender plates of ferrite, nano-films, as those shown in Fig. 4 and Fig. 6, also have a size $<100 \mathrm{~nm}$. In the past, the term block of austenite has been used to describe unetched surface pools of austenite with sizes of several tens of micrometres trapped between sheaves of bainite. In low-temperature bainitic alloys, the term micro-block is used to denote blocks of retained austenite $>1000 \mathrm{~nm}$, and sub-micron blocks those between 100 and $1000 \mathrm{~nm}$.

Morphology is an important factor to be considered on the mechanical stability of austenite. In terms of its mechanical stability, thin films of retained austenite can be too stable $[29,30]$ to transform by transformation-induced plasticity (TRIP) effect, for several reasons. First, because of the constraint to transformation exerted by the surrounding plates of ferrite, second, because smaller retained austenite contain lower potential nucleation sites for the transformation to martensite therefore requiring higher driving force for martensite nucleation, and finally, because their higher carbon concentration [31].

The chemical composition is also an important factor controlling the mechanical stability of austenite. Elements such as carbon, manganese, and silicon [32,33] significantly enhance the austenite mechanical stability; amongst these elements, carbon exhibits the strongest influence. In alloys containing austenite of low mechanical stability, the strain-induced transformation occurs during the early stages of deformation, resulting in little or no benefit of the strain hardening related to deterring plastic instability or necking in the later stages of deformation. Conversely, if austenite becomes mechanically more stable and transforms at higher strains, the associated strain hardening effectively increases resistance to necking and fracture. However, if austenite is too stable, the presence of large amounts of austenite at necking (instability criterion) does not guarantee effective TRIP effect. So, the strain-induced transformation will enhance ductility if retained austenite is moderately stable against straining.

Therefore, a wide distribution of sizes of the retained austenite in the microstructure, as illustrated in Fig. 6, will lead to effective variations of the austenite stability, and would be favourable for spreading the effect of the transformation all along straining and for postponing localization [34,35]. As it has been mentioned, and Fig. 7 illustrates at an atomic level for these type of alloys [36,37], there is a strong correlation between the 
size of the austenite feature and the amount of $\mathrm{C}$ that is retained in solid solution, i.e., the smaller the size, the higher the amount of carbon present. Therefore, it can be concluded that a wider distribution of austenite sizes, wider range of levels of mechanical stabilities, might provide an extra contribution to ductility [12].

\section{High density of defects}

Plastic relaxation in the austenite adjacent to the bainitic ferrite during bainite reaction may control the final size of the bainitic ferrite plates [38]. The defects generated in this process resist the advance of the bainitic ferrite-austenite interface, where the defect density is highest for lower transformation temperatures [39]. The plastic relaxation of the shape change was examined a long time ago by in-situ hot-stage transmission electron microscopy (TEM) and pre-polished samples of austenite transforming to bainite. Observations revealed that the growth of bainite is accompanied by the formation of dislocations in and around the bainite [40].

The retained austenite was also found to have the appearance of multiple planar faults/twins, often with one dominant fault plane [31]. When the fault plane was approximately normal to the foil plane, the faults could be seen to terminate at slip steps in the austenite/ferrite interface indicative of accommodation slip on $\{111\}_{\gamma}$ planes during the displacive transformation [31].

Cornide et al. [41] determined the dislocation densities in the bainitic ferrite and austenite phases in nanostructured bainitic steels by TEM to be $(5.1 \pm 2.7) \times 10^{14} \mathrm{~m}^{-2}$ and $(1.8 \pm 0.2) \times 10^{14} \mathrm{~m}^{-2}$, respectively [41]. These values are higher than those reported for conventional bainite, $1.7-4.0 \times 10^{14} \mathrm{~m}^{-2}$ [42] and, in general terms, similar to those measured for martensitic microstructures [43]. A progressive increase in the dislocation density in bainitic ferrite was also observed as the austenite/bainitic ferrite interface is approached [41]. This increase is related to the plastic deformation occurring in the surrounding austenite that accommodates the transformation strain as growth progresses and the following inheritance of those dislocations by the expansion of the growing bainitic ferrite plate [41].

Complementary atom probe tomography results revealed carbon trapping at dislocations in the vicinity of a bainitic ferrite-austenite interface, as shown in Fig. 8. The distribution of the carbon atoms in the analysis volume is not uniform and carbon-rich and carbon-depleted regions are clearly distinguishable. The carbon-enriched region at the top right of the atom map (Fig. 8b) represents austenite and the low carbon regions 
indicate the bainitic ferrite phase. Finally, the linear features with significant levels of carbon are dislocations in the vicinity of a bainitic ferrite-austenite interface. The 6 at.\% $\mathrm{C}$ isoconcentration surface shown in Fig. 8b outlines the carbon-enriched region around a dislocation. It is evident from the proximity histograms across the dislocation in Fig. 8c that dislocations only trap the carbon atoms, as originally suggested by Kalish and Cohen [44]. As a result of the large distortion caused by the supersaturated carbon in the ferrite lattice, there is an attraction between carbon atoms and the stress fields of the dislocations [45]. Carbon tends to diffuse to sites close to dislocations in order to reduce its chemical potential.

\section{Nanoscale carbides}

The precipitation of carbides during the bainite reaction is a secondary process, not essential to the mechanism of formation of bainitic ferrite, except where any precipitation influences the reaction rate by removing carbon either from the residual austenite or from the supersaturated ferrite [46,47]. In upper bainite, the carbides precipitate from the carbon-enriched residual austenite between the developing laths. Thus, upper bainitic ferrite itself is generally free from intralath precipitates. In contrast, many observations reveal that lower bainitic cementite nucleates and grows within supersaturated bainitic ferrite in a process identical to the tempering of martensite [48]. The slower diffusion associated with the reduced transformation temperature provides an opportunity for some of the carbon to precipitate in the supersaturated bainitic ferrite. A fine dispersion of plate-like carbides is then found inside the bainitic ferrite, which also has a plate morphology, with a single crystallographic variant within a given bainitic ferrite plate, although it is possible to observe more than one variant of carbide precipitation in a lower bainite sub-unit $[48,49]$.

Remarkably, the TEM micrograph shown in Fig. 4 failed to reveal carbide particles inside the bainitic ferrite after transformation at $125^{\circ} \mathrm{C}$ in NANOBAIN 1 steel, leading to the doubtful hypothesis that upper bainite was formed at this extremely low temperature. As mentioned above, only after extensive aging at $200{ }^{\circ} \mathrm{C}$ for 14 days in the same steel, just a few $20 \mathrm{~nm}$ wide and $175 \mathrm{~nm}$ long cementite particles were observed by TEM inside a thicker bainitic ferrite plate [2]. The presence of intra-lath cementite as the lower bainite carbide in nanostructured bainitic steels was later confirmed by atom probe tomography [50]. An example of a carbon atom map showing carbon segregation across a cementite particle in nanostructure bainitic steels is shown 
in Fig. 9. Cementite particles ideally contain a carbon content of 25 at. \%; however, an apparent low carbon concentration of cementite was reported in earlier atom probe studies [51,52]. This is primarily due to the assignment of the carbon peak at a mass-tocharge state ratio of $12 \mathrm{Da}$ to be exclusively $\mathrm{C}^{+}$rather than containing some $\mathrm{C}_{2}^{++}$ions, which will lead to a small underestimate of the true carbon level. However, all the particles detected with this level of carbon also show evidences of substitutional solute partitioning across the interface. The proximity histogram in Fig. 9 shows substitutional solute partitioning across the interface. This additional information helps to identify cementite.

As illustrated above, defects can effectively be thought of as separate trapping sites, which are a greater attractor for carbon than cementite. In these circumstances, the carbon available for cementite precipitation is reduced. The rate of precipitation then depends on the removal of defects during annealing, making more carbon available for cementite formation [53]. This process must greatly retard tempering kinetics and, because of the reduced carbon concentration in the perfect lattice, lead to a smaller driving force for precipitation.

\section{Carbon supersaturation in ferrite}

In addition, atom probe tomography revealed the presence of a high level of carbon in bainitic ferrite, which was well above that expected from para-equilibrium with austenite once the reaction proceeds to completion [50]. This reluctance of the carbon to partition was firstly attributed to the carbon trapping at dislocations in the vicinity of the austenite-ferrite interface, and to the fact that the lower the reaction temperature, the higher dislocation density of bainitic ferrite. However, recent work [54] has also shown by atom probe tomography, Fig. 10, that as the transformation temperature is decreased, a higher amount of carbon remains in defect-free solid solution in the bainitic ferrite after transformation. In fact, the recorded concentration profiles revealed that the carbon content is rather homogeneously distributed within each phase indicating that carbon had sufficient time to be distributed to a state close to certain kind of equilibrium that is independent of the initial distribution between bainitic ferrite and parent austenite. An interesting question is what factors have caused the abnormally high carbon solubility in bainitic ferrite. Bhadeshia and co-workers [55] explained this abnormally high carbon content in ferrite using first-principles calculations and suggested that when tetragonal ferrite is in equilibrium with austenite, it has a much greater solubility for 
carbon than is the case for cubic ferrite in the same circumstances. Likewise, they provided experimental evidences for the existence of a tetragonal or slightly orthorhombic unit cell of bainitic ferrite that supports the hypothesis that the excess carbon that persists in the ferrite is a consequence of an increased solubility due to the change in symmetry from the conventional cubic unit cell [56].

\section{Summary}

Nanostructured bainitic steels have been designed and manufactured following conventional industrial practices. Their microstructure consists of extremely fine plates of carbon-supersaturated ferrite and retained austenite. The designed steels present mechanical properties never achieved before with bainite and the potential use of these steels is large.

\section{Acknowledgements}

The authors gratefully acknowledge the support of the Spanish Ministry of Science and Innovation for funding this research under the contract MAT2010-15330, respectively. Atom probe tomography research (MKM) was supported through a user project supported by ORNL's Center for Nanophase Materials Sciences (CNMS), which is sponsored by the Scientific User Facilities Division, Office of Basic Energy Sciences, U.S. Department of Energy. 
Table 1 Chemical composition of nanostructured bainitic steels, wt.\%.

\begin{tabular}{lllllllllll}
\hline Steel & $\mathrm{C}$ & $\mathrm{Si}$ & $\mathrm{Mn}$ & $\mathrm{Cr}$ & $\mathrm{Mo}$ & $\mathrm{V}$ & $\mathrm{Nb}$ & $\mathrm{Co}$ & $\mathrm{Al}$ \\
\hline
\end{tabular}

First Generation:

$\begin{array}{llllllllll}\text { NANOBAIN } 1 & 0.79 & 1.59 & 1.94 & 1.33 & 0.30 & 0.11 & - & -\end{array}$

$\begin{array}{lllllllll}\text { NANOBAIN } 2 & 0.83 & 1.57 & 1.98 & 1.02 & 0.24 & - & - & 1.54\end{array}$

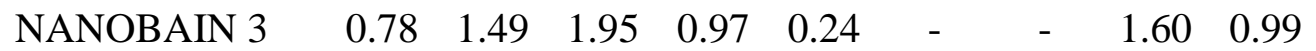

Second Generation:

$\begin{array}{lllllllll}\text { NANOBAIN } 4 & 0.99 & 1.58 & 0.76 & 0.45 & - & - & - & -\end{array}$

$\begin{array}{lllllllll}\text { NANOBAIN } 5 & 1.00 & 1.53 & 0.75 & 0.51 & - & - & 0.02 & -\end{array}$

$\begin{array}{lllllllll}\text { NANOBAIN } 6 & 1.01 & 1.51 & 0.82 & 0.46 & 0.10 & - & - & -\end{array}$

$\begin{array}{llllllllll}\text { NANOBAIN } 7 & 0.98 & 2.90 & 0.77 & 0.45 & - & - & - & -\end{array}$

$\begin{array}{lllllllll}\text { NANOBAIN } 8 & 0.88 & 1.54 & 0.69 & 0.50 & - & - & - & -\end{array}$

$\begin{array}{llllllllll}\text { NANOBAIN } 9 & 0.67 & 1.60 & 1.25 & 1.50 & - & - & - & - & -\end{array}$

NANOBAIN $10 \quad 0.61 \quad 1.45 \quad 0.76 \quad 2.42$

$\begin{array}{lllllllllll}\text { NANOBAIN } 11 & 0.64 & 1.60 & 1.27 & 1.50 & - & - & 0.03 & - & -\end{array}$

$\begin{array}{llllll}\text { NANOBAIN } 12 & 0.58 & 1.63 & 1.29 & 1.43 & 0.1\end{array}$ 
Table 2 Tensile test and microstructural characterization results on selected grades and conditions.

\begin{tabular}{cccccccc}
\hline Alloy & $\mathrm{T} /{ }^{\circ} \mathrm{C}$ & YS/MPa & UTS/MPa & UE/ \% & $\mathrm{TE} / \%$ & $\mathrm{~V}_{\gamma} / \%$ & $\mathrm{t} / \mathrm{nm}$ \\
\hline \multirow{2}{*}{ NANOBAIN 6 } & 200 & 2019 & 2091 & 0.37 & 0.38 & 20 & 21 \\
& 250 & 1852 & 2164 & 2.86 & 8.29 & 22 & 32 \\
\hline \multirow{2}{*}{ NANOBAIN 7 } & 220 & 1704 & 2287 & 7.37 & 7.37 & 36 & 32 \\
& 250 & 1698 & 2068 & 11.62 & 21.32 & 34 & 32 \\
\hline \multirow{2}{*}{ NANOBAIN 8 } & 220 & 1931 & 2329 & 3.19 & 4.1 & 22 & 32 \\
& 270 & 1701 & 2036 & 4.44 & 12.64 & 24 & 36 \\
\hline
\end{tabular}

T: isothermal transformation temperature; YS: yield strength; UTS: ultimate tensile strength; UE: uniform elongation; TE: total elongation; $\mathrm{V}_{\gamma}$ : austenite volume fraction; $\mathrm{t}$ : bainitic ferrite plate thickness 


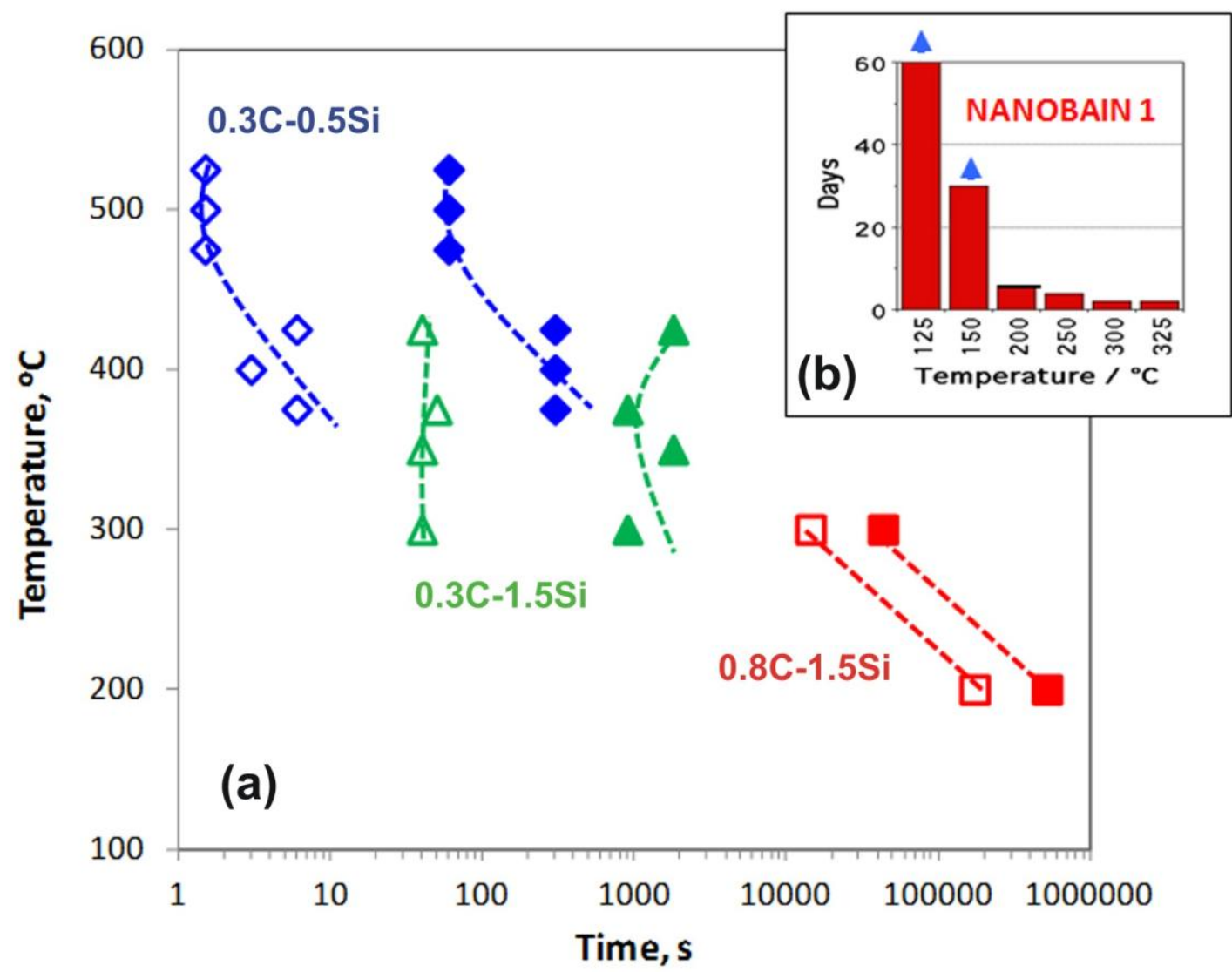

Fig. 1. (a) Kinetics results in terms of start and finish bainite reaction times as a function of transformation temperature in steels with different carbon and silicon contents with the approximated composition of $\mathrm{Fe}-\mathrm{XC}-\mathrm{YSi}-1.5 \mathrm{Mn}-0.5 \mathrm{Cr}$ (wt.\%). (b) Histogram shows the required time (in days) to complete bainite reaction at different temperatures in the first generation of nanostructured bainitic steels (NANOBAIN 1 steel). 


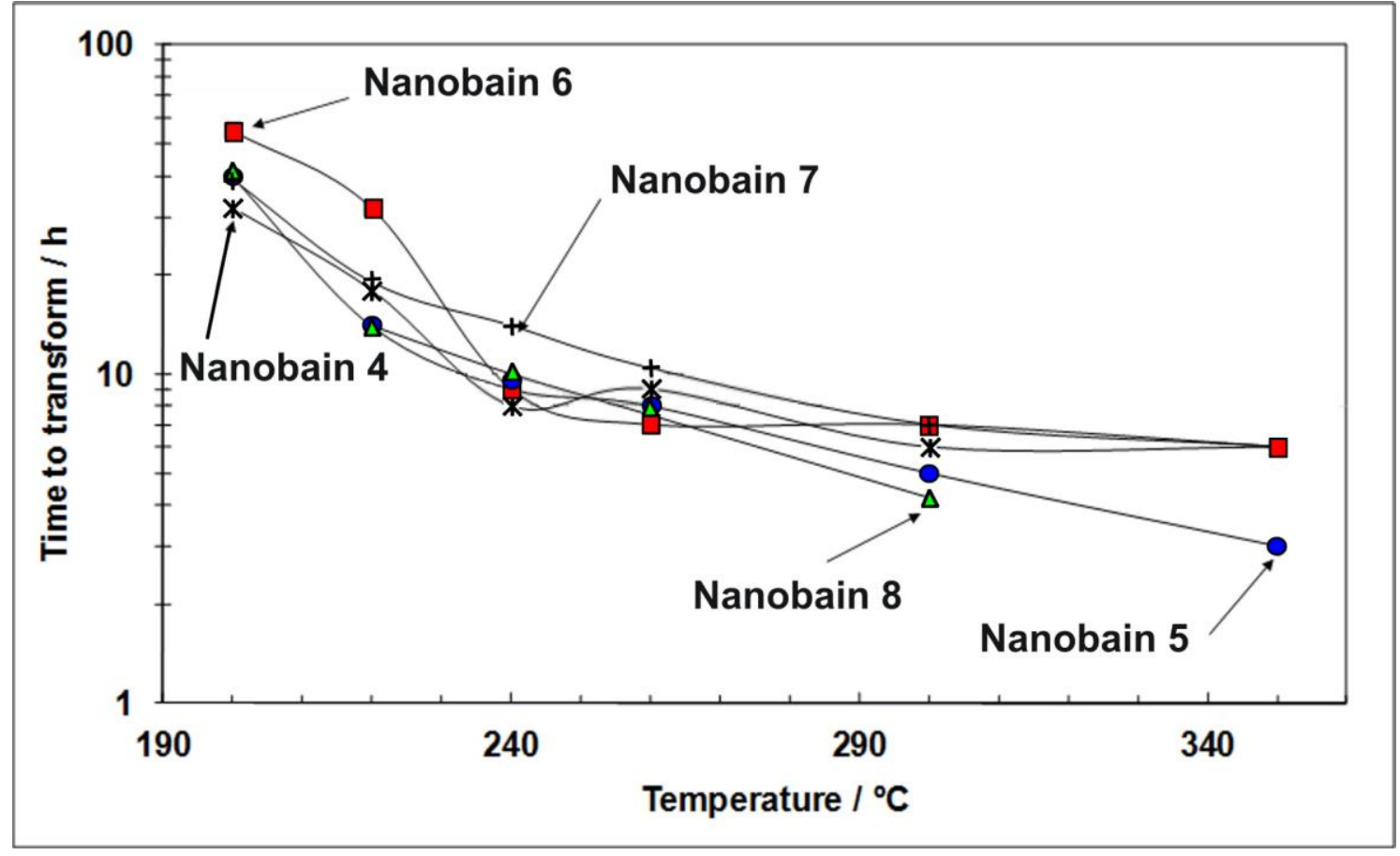

Fig. 2. Examples of the required time (in hours) to complete bainite reaction at different temperatures in the second generation of nanostructured bainitic steels. 


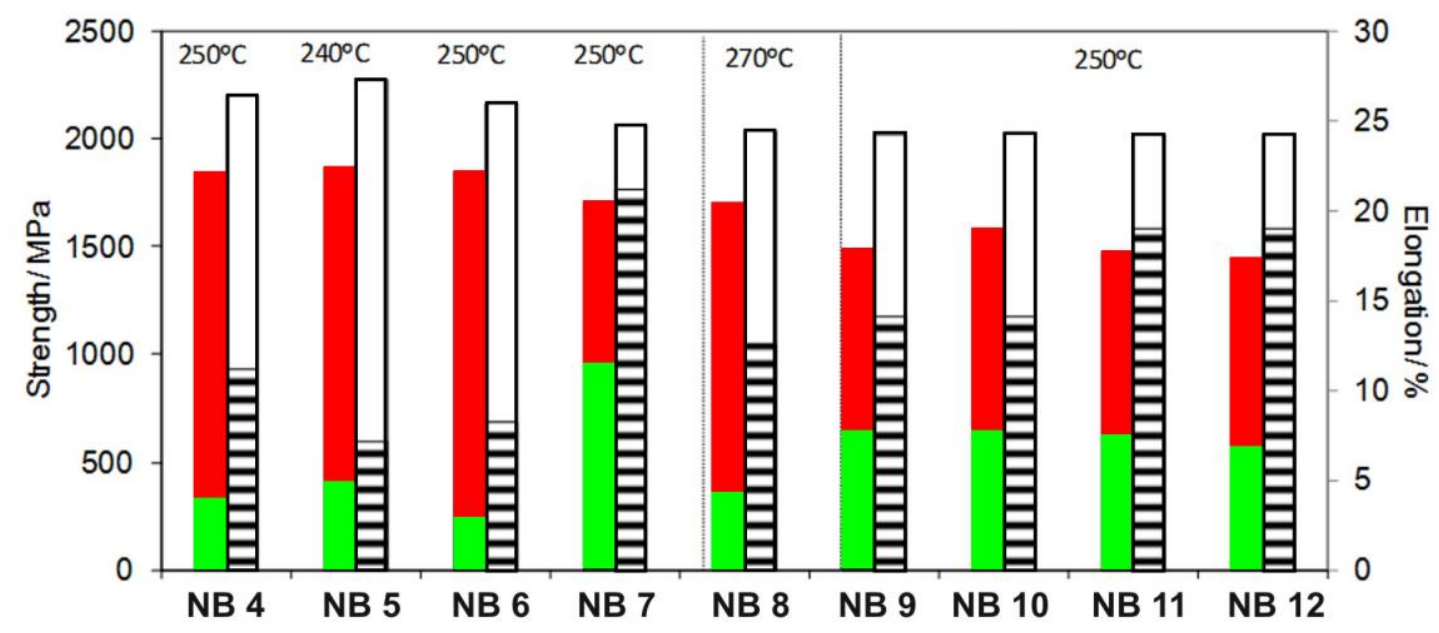

口YS DUTS EUniform 日Total Steels

Fig. 3. Relevant tensile properties of second generation of nanostructured bainitic steels. NB is NANAOBAIN. The temperature indicated refers to that of the isothermal transformation. 


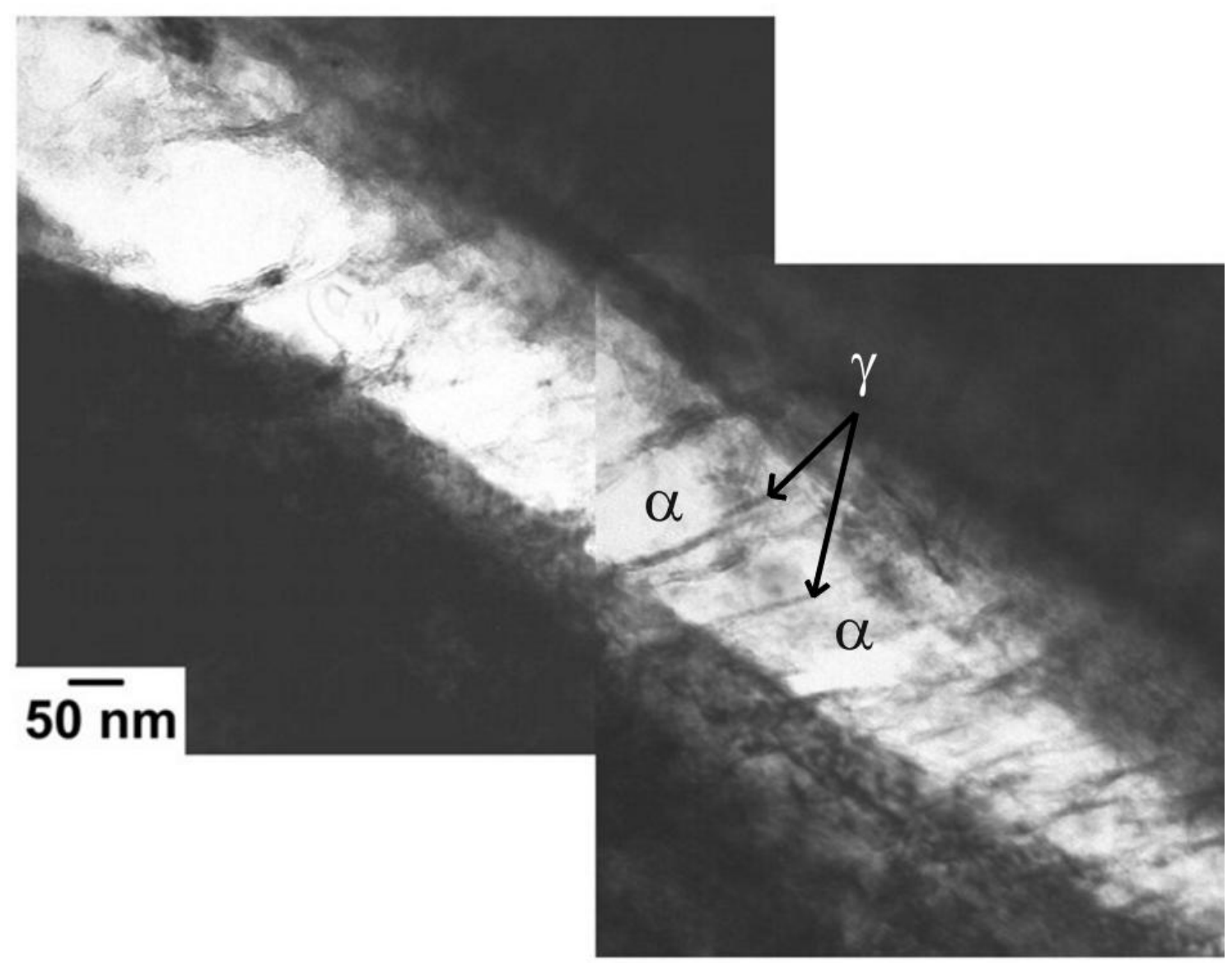

Fig. 4. Transmission electron micrographs of microstructure obtained at $125^{\circ} \mathrm{C}$ for 60 days in NANOBAIN 1 steel. 
(a)

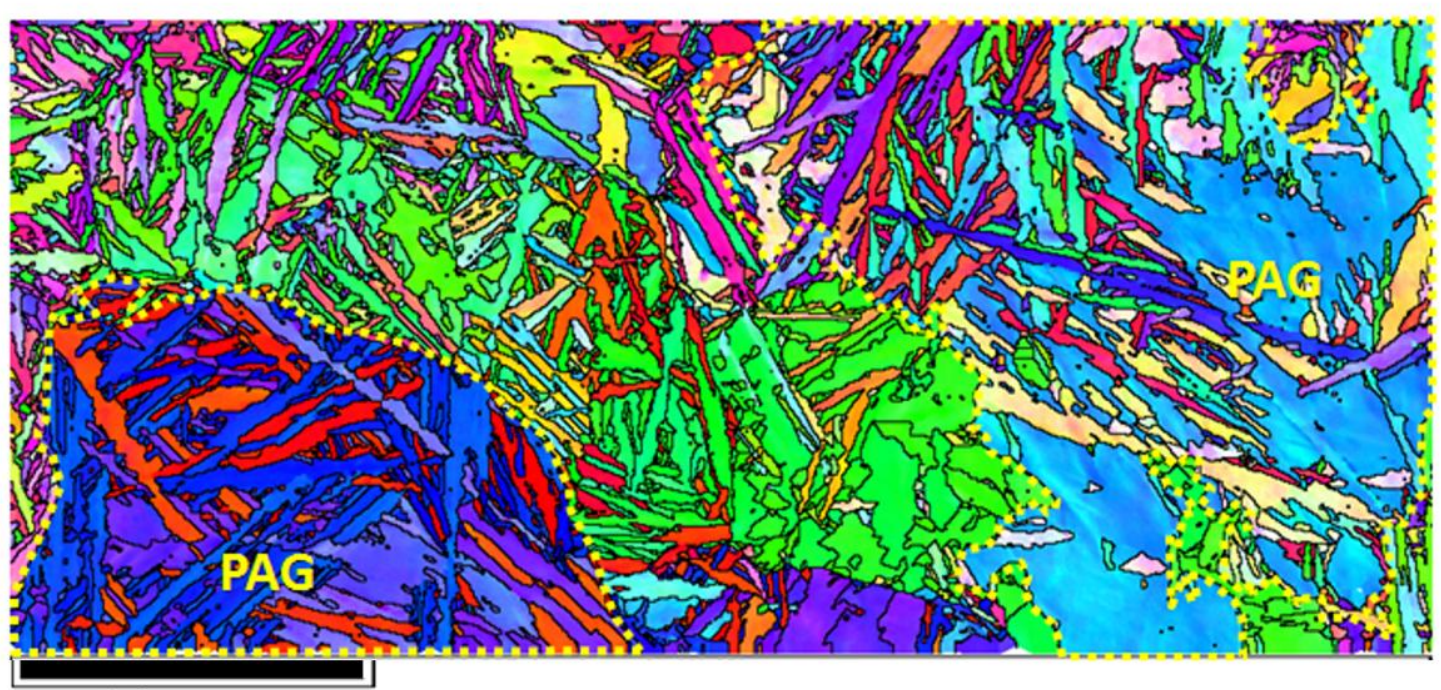

$20 \mu \mathrm{m}$

(b)

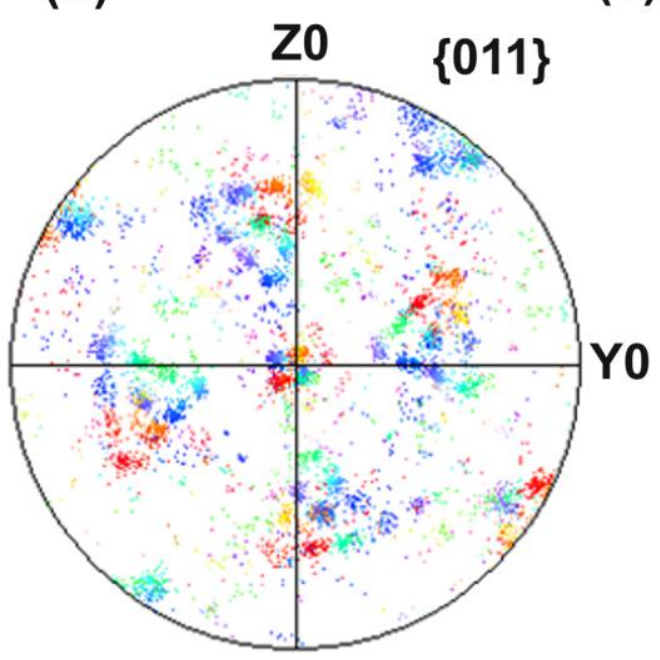

(c)

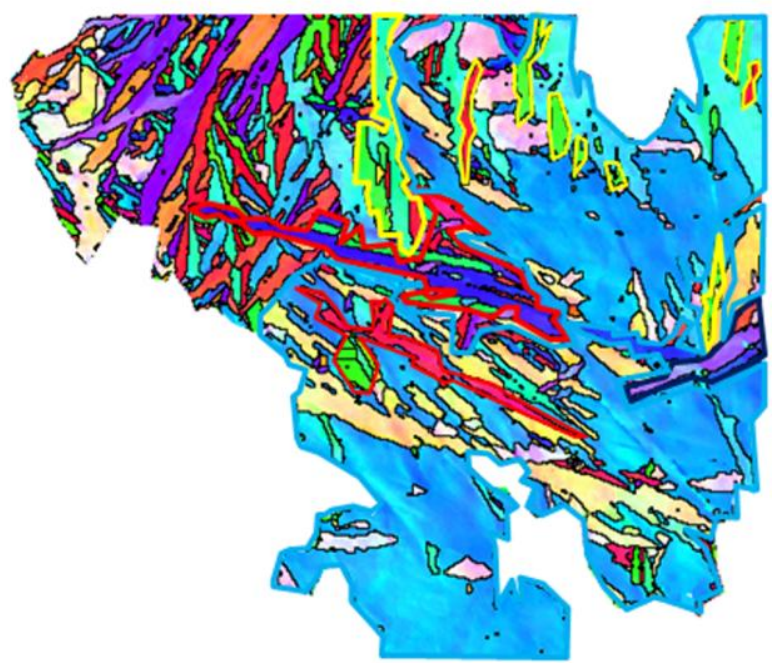

Fig. 5. (a) The inverse pole figure of NANOBAIN 9 transformed to bainite at $250{ }^{\circ} \mathrm{C}$. The black thin line represents the misorientation angles greater than $10^{\circ}$ and the dashed yellow coarse line represent selected prior austenite grain boundaries; (b) $\{011\}$ pole figure representing orientations of bainite laths corresponding to (a); (c) enlarged prior austenite grain delimitated in (a). The different coarse lines represent the packet boundaries. 


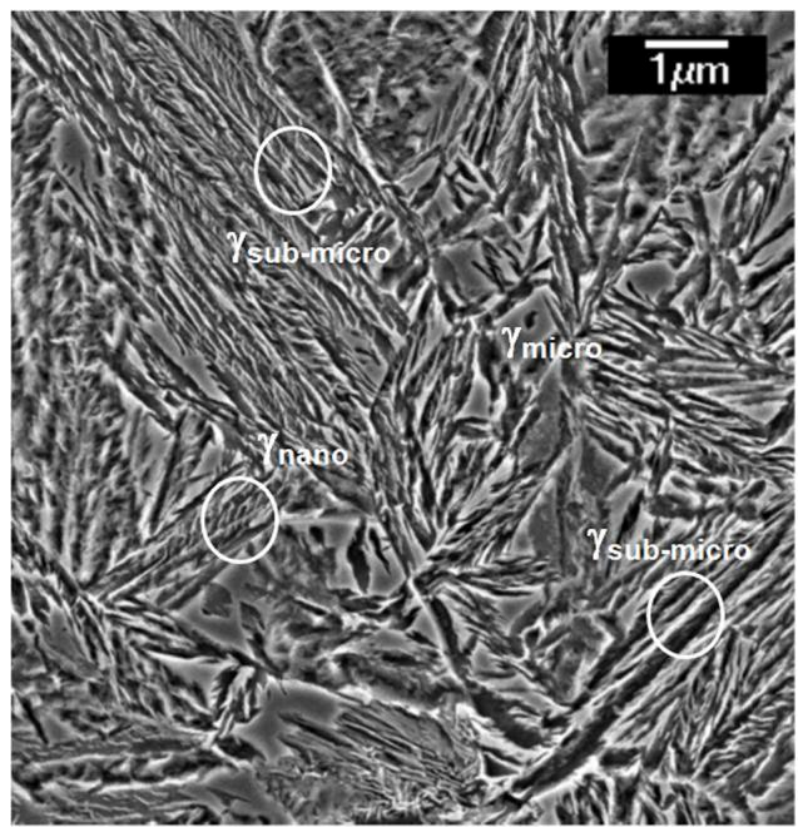

Fig. 6. Example of scanning electron micrograph of microstructures obtained in NANOBAIN 7 by isothermal transformation at $220^{\circ} \mathrm{C}$. 
Nanoscale Austenite films

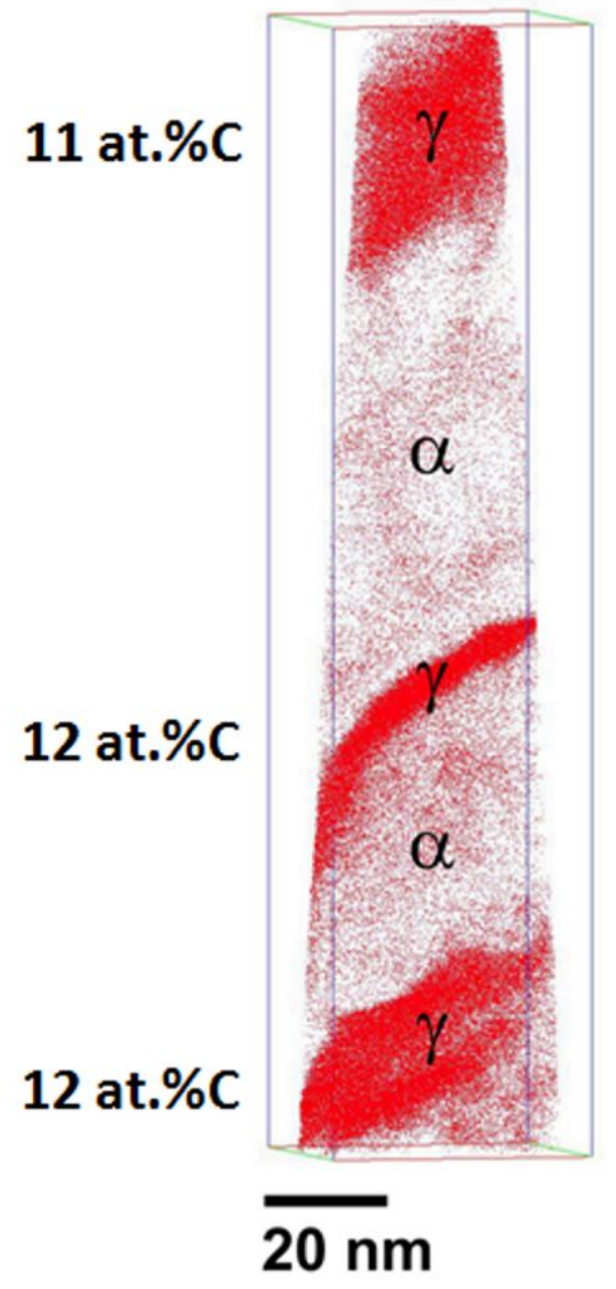

Sub-micron Austenite block

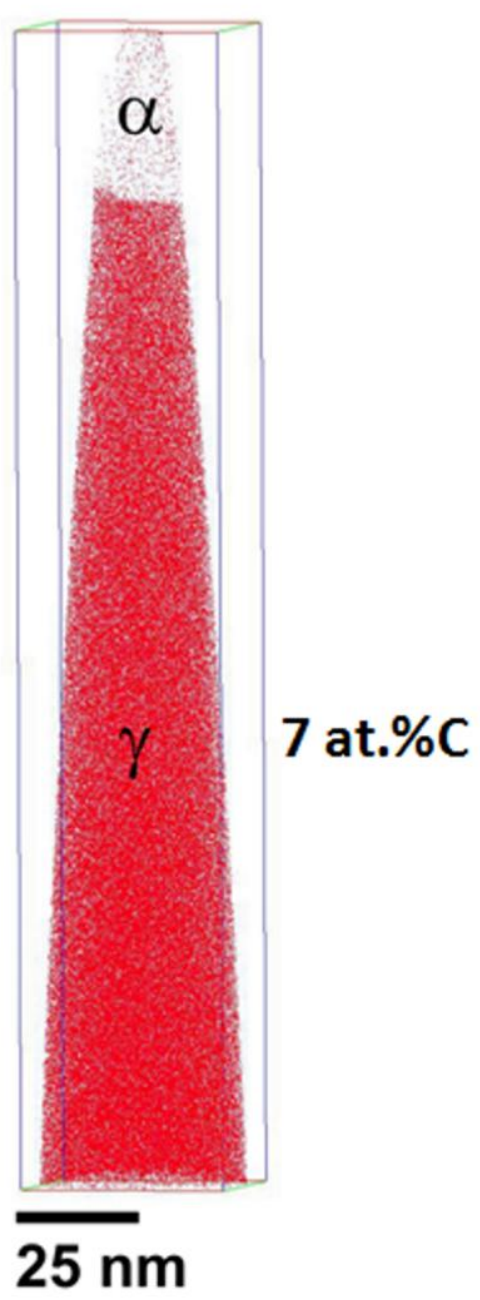

Fig. 7. Examples of carbon atom maps and corresponding carbon content for nano-scale films of austenite and sub-micron blocky austenite. 

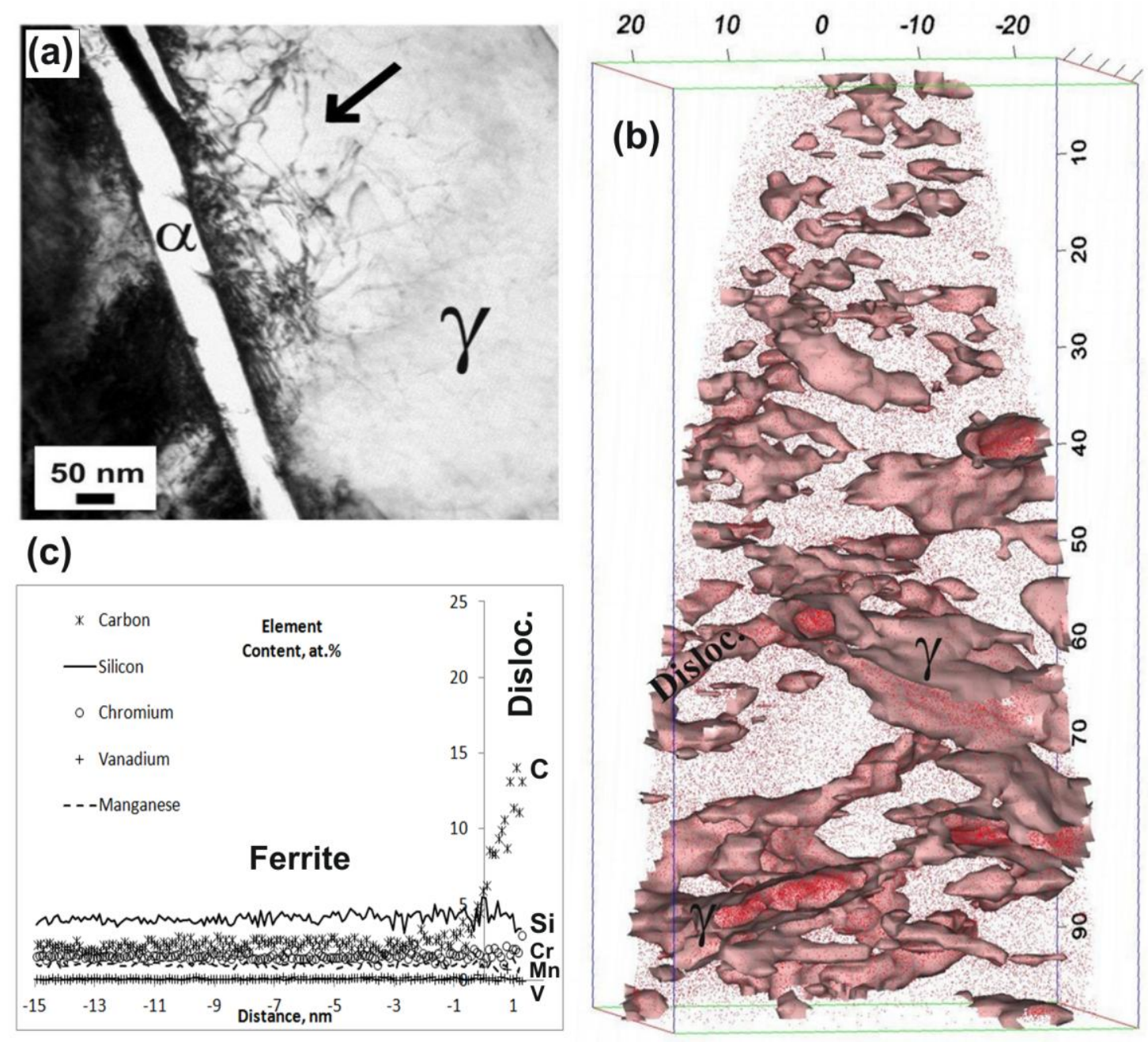

Fig. 8. (a) Transmission electron micrograph, and corresponding (b) carbon isoconcentration surfaces at 6 at. $\% \mathrm{C}$, and (c) proximity histograms across a dislocation in ferrite in the vicinity of two austenite plates. 

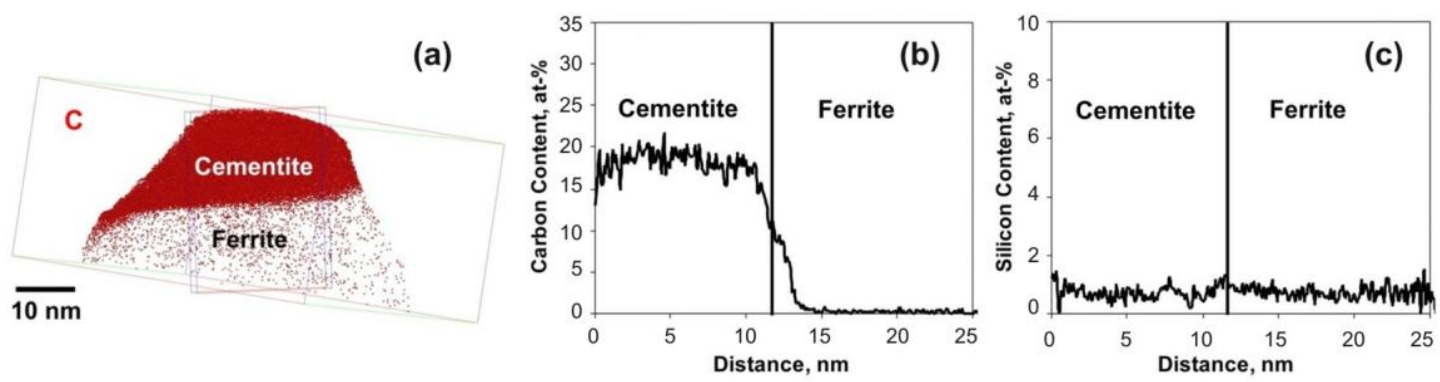

Fig. 9. (a) Carbon atom map and concentration profiles showing distribution of (b) carbon and (c) silicon across a cementite/ferrite interface during bainite transformation at $200^{\circ} \mathrm{C}$ in NANOBAIN 1. 


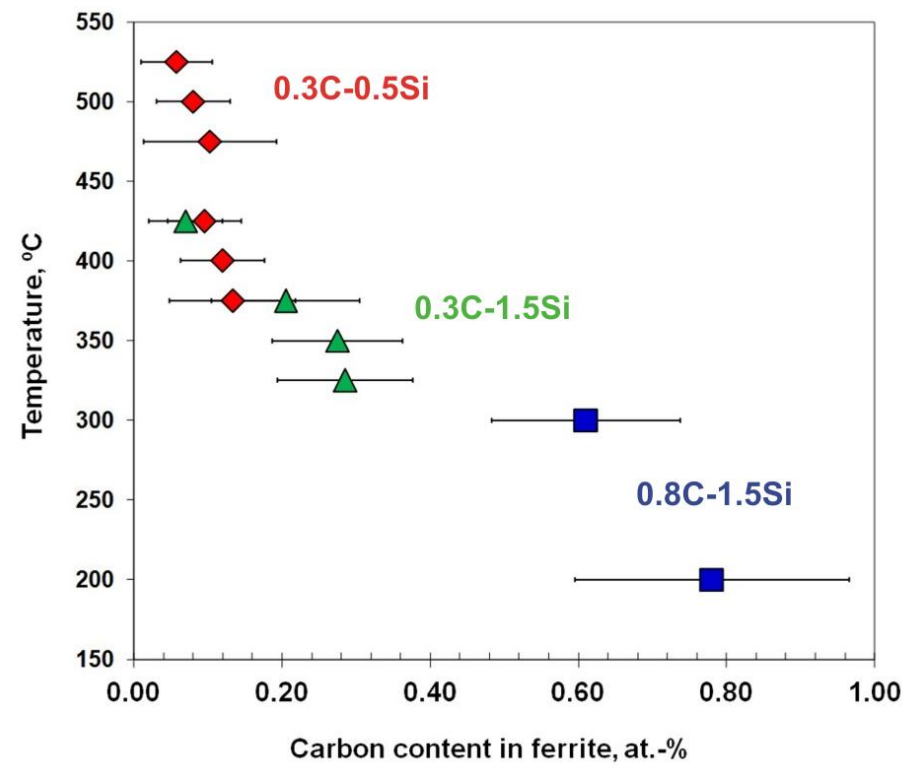

Fig. 10. Carbon content in bainitic ferrite determined by atom probe tomography after bainite reaction at different temperatures in steels with the approximated composition of Fe-XC-YSi-1.5Mn-0.5Cr (wt.-\%). 


\section{References}

1 F. G. Caballero and C. Capdevila: Mater. Sci. Technol., 2013, vol.29, pp. 1149-51.

2 F. G. Caballero, H. K. D. H. Bhadeshia, K. J. A. Mawella, D. G. Jones and P. Brown: Mater. Sci. Technol., 2002, vol.18, pp. 279-84.

3 C. Garcia-Mateo, F. G. Caballero and H. K. D. H. Bhadeshia: ISIJ Int., 2003, vol.43, pp. 1238-43.

4 H. K. D. H. Bhadeshia: Mater. Sci. Technol., 2005, vol.21, pp. 1293-302.

5 M. Soliman and H. Palkowski: ISIJ Int., 2007, vol.47, pp. 1703-10.

6 P. Hodgson, I. Timokhina, X. Xiong, A. Yoshitaka and H. Beladi, Solid State Phenom., 2011, vol.172-174, pp. 123-8.

7 I. B. Timokhina, H. Beladi, X. Y. Xiong, Y. Adachi and P. D. Hodgson: Acta Mater., 2011, vol.59, pp. 5511-22.

8 J. A. Da Cruz Junior, T. F. M. Rodrigues, V. D. C. Viana and D. B. Santos, Mater. Sci. Forum, 2012, vol.706-709, pp. 173-80.

9 C. Garcia-Mateo, F.G. Caballero, T. Sourmail, V. Smanio and C. Garcia de Andres. "Composition Design Of Nanocrystalline Bainitic Steels By Diffusionless Solid Reaction”. In press Metallic Materials International.

10 'Heat-treated steels, alloy steels and free-cutting steels - Part 17: ball and roller bearing steels', ISO 683-17:1999, ISO, Geneva, Switzerland, 1999

11 C. Garcia-Mateo and F. G. Caballero: ISIJ Int., 2005, vol.45, pp. 1736-40.

12 C. Garcia-Mateo, F. Caballero, T. Sourmail, M. Kuntz, J. Cornide, V. Smanio and R. Elvira: Mater. Sci. Eng. A, 2012, vol.549, pp. 185-92.

13 A. Leiro, E. Vuorinen, K. G. Sundin, B. Prakash, T. Sourmail, V. Smanio, F. G. Caballero, C. Garcia-Mateo and R. Elvira: Wear, 2013, vol.298, pp. 42-7.

14 T. Sourmail, F. G. Caballero, C. Garcia-Mateo, V. Smanio, C. Ziegler, M. Kuntz, R. Elvira, A. Leiro, E. Vuorinen and T. Teeri: Mater. Sci. Technol., 2013, vol.29, pp. 116673.

15 C. Garcia-Mateo and H. K. D. H. Bhadeshia: Mater. Sci. Eng. A, 2004, vol.378, pp. 289-92.

16 F. G. Caballero and H. K. D. H. Bhadeshia: Curr. Opin. Solid State Mat. Sci., 2004, vol.8, pp. 251-7. 
17 F. G. Caballero, M. K. Miller, C. Garcia-Mateo, C. Capdevila and C. Garcia de Andrés: $J O M, 2008$, vol.60, pp. 16-21.

18 Q. Zhu, C. M. Sellars and H. K. D. H. Bhadeshia: Mater. Sci. Technol., 2007, vol.23, pp. 757-66.

19 S. Chatterjee, H. S. Wang, J. R. Yang and H. K. D. H. Bhadeshia: Mater. Sci. Technol., 2006, vol.22, pp. 641-4.

20 C. Garcia-Mateo, F. G. Caballero and H. K. D. H. Bhadeshia: ISIJ Int., 2003, vol.43, pp. 1821-5.

21 H. K. D. H. Bhadeshia in Mathematical Modelling of Weld Phenomena III. (Institute of Materials, London, 1997),pp. 229-84.

22 G. Langford and M. Cohen: ASM-Trans, 1969, vol.62, pp. 623-38.

23 G. Langford and M. Cohen: Metall. Mater. Trans. A, 1970, vol.1, pp. 1478-80.

24 C. Garcia-Mateo and F. G. Caballero: Mater. Trans. JIM, 2005, vol.46, pp. 1839-46.

25 H. K. D. H. Bhadeshia, Bainite in Steels. Transformations, Microstructure and Properties,2nd ed. ( Institute of Materials, Minerals and Mining, London, 2001).

26 A. R. Marder and G. Krauss: Trans ASM, 1967, vol.60, pp. 651-60.

27 S. Matsuda, T. Inoue and M. Ogasawara: Trans JIM 1968, vol.9, pp. 343-8.

28 T. Furuhara, H. Kawata, S. Morito and T. Maki: Mater. Sci. Eng. A, 2006, vol.431, pp. 228-36.

29 C. A. N. Lanzillotto and F. B. Pickering: Met. Sci., 1982, vol.16, pp. 371-82.

30 N. K. Balliger and T. Gladman: Met. Sci., 1981, vol.15, pp. 95-108.

31 H. K. D. H. Bhadeshia and D. V. Edmonds: Metall. Trans. A, 1979, vol.10, pp. 895907.

32 P. J. Jacques, E. Girault, A. Mertens, B. Verlinden, J. Van Humbeeck and F. Delannay: ISIJ Int., 2001, vol.41, pp. 1068-74.

33 K. Nohara, Y. Ono and N. Ohashi: Tetsu To Hagane-J. ISIJ, 1977, vol.63, pp. 21222.

34 F. Lani, Q. Furnemont, T. Van Rompaey, F. Delannay, P. J. Jacques and T. Pardoen: Acta Mater., 2007, vol.55, pp. 3695-705.

35 K. Hase, C. Garcia-Mateo and H. K. D. H. Bhadeshia: Mater. Sci. Eng. A, 2006, vol.438-440, pp. 145-8.

36 C. Garcia-Mateo, F. G. Caballero, M. K. Miller and J. A. Jimenez: J. Mater. Sci., 2012, vol.47, pp. 1004-10. 
37 F. G. Caballero, M. K. Miller, A. J. Clarke and C. Garcia-Mateo: Scr. Mater., 2010, vol.63, pp. 442-5.

38 L. C. Chang and H. K. D. H. Bhadeshia: Mater. Sci. Technol., 1995, vol.11, pp. 1058.

39 M. K. Fondekar, A. M. Rao and A. K. Mallik: Metall. Trans. A, 1970, vol.1, pp. 88590.

40 M. Nemoto, High Voltage Electron Microscopy, (Academic Press, New York NY, 1974).

41 J. Cornide, G. Miyamoto, F. G. Caballero, T. Furuhara, M. K. Miller and C. GarciaMateo: Solid State Phenom., 2011, vol.172-174, pp. 117-22.

42 G. M. Smith, The Microstructure and Yielding Behaviour of Some Ti Steels [Dissertation], University of Cambridge, 1984.

43 S. Morito, J. Nishikawa and T. Maki: ISIJ Int., 2003, vol.43, pp. 1475-7.

44 D. Kalish and M. Cohen: Mater. Sci. Eng. A, 1970, vol.6, pp. 156-66.

45 A. H. Cottrell and B. A. Bilby: Proc Phys Soc 1949, vol.62A, pp. 49-61.

46 H. K. D. H. Bhadeshia and J. W. Christian: Metall. Trans. A, 1990, vol.21 A, pp. 767-97.

47 M. Takahashi and H. K. D. H. Bhadeshia: Mater. Sci. Technol., 1990, vol.6, pp. 592603.

48 H. K. D. H. Bhadeshia: Acta Metall., 1980, vol.28, pp. 1103-14.

49 L. C. Chang: Mater. Sci. Eng. A, 2004, vol.368, pp. 175-82.

50 F. G. Caballero, M. K. Miller, S. S. Babu and C. Garcia-Mateo: Acta Mater., 2007, vol.55, pp. 381-90.

51 M. K. Miller, P. A. Beaven, S. S. Brenner and G. D. W. Smith: Metall. Trans. A, 1983, vol.14 A, pp. 1021-4.

52 S. S. Babu, K. Hono and T. Sakurai: Metall. Mater. Trans. B, 1994, vol.25, pp. 499508.

53 T. D. Bigg, D. K. Matlock, J. G. Speer and D. V. Edmonds: Solid State Phenomena, 2011, vol.172-174, pp. 827-32.

54 F. G. Caballero, M. K. Miller and C. Garcia-Mateo: Acta Mater., 2010, vol.58, pp. 2338-43. 
55 J. H. Jang, H. K. D. H. Bhadeshia and D.-W. Suh: Scr. Mater., 2013, vol.68, pp. 1958.

56 C. N. Hulme-Smith, I. Lonardelli, A. C. Dippel and H. K. D. H. Bhadeshia: Scr. Mater., 2013, vol.69, pp. 409-12. 